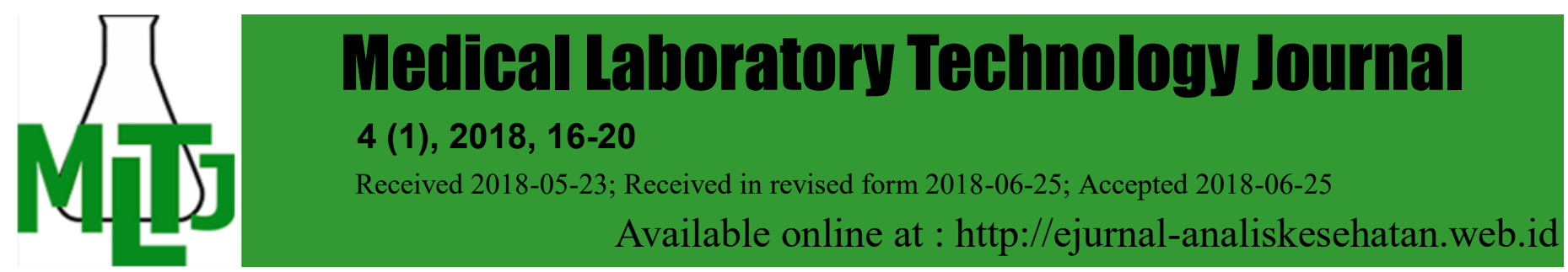

\title{
LIME SOAP AS BACTERIA REDUCER
}

\author{
Ratih Dewi Dwiyanti, Leka Lutpiatina \\ Medical Laboratory Technology Poltekkes Kemenkes Banjarmasin \\ Mistar Cokrokusumo Street 4a Banjarbaru Indonesia. \\ e-mail: Ratihdewi262@yahoo.co.id
}

\begin{abstract}
Some people in South Kalimantan have used river water to fulfill their daily needs include washing the utensils. Wash the cutlery use river water can cause disease transmission. Squeezed lime has an antibacterial effect in inhibiting bacterial growth. Antibacterial dishwashing soap is effective in reducing pathogenic bacteria. This research is to know the difference of bacterial amount on the variation of contact time with soap. Know the difference of bacteria on the variation of concentration of lime soap and soap without lime. The study used the experimental method with pretest and posttest with control design. The independent variables are a lime soap with a concentration of $40 \%, 50 \%, 60 \%$ and variable of contact time 30 second, 60 second and 90 seconds. The dependent variable is the number of bacteria on the dinnerware of a dinner plate. The data obtained in this study is the data of measurement of the number of bacteria on the dinner plate. Data analyzed by Kruskal-Wallis test. MPN coliform examination of river water showed results $>2400 \mathrm{CFU} / \mathrm{ml}$ sample. There were no significant differences in treatment with contact time variation of 30 seconds, 60 seconds and 90 seconds. The significance value is $0.796(>0.05)$. There were significant differences in the treatment of lime soap with concentration variations of $40 \%, 50 \%, 60 \%$, and soap without lime. The value of significance is $0,000(<0.05)$.
\end{abstract}

Keywords: Soap; Lime; Number of bacteria

\section{INTRODUCTION}

The World Health Organization reports that 1.6 million people die each year from diarrheal diseases due to lack of access to safe drinking water and basic sanitation. $90 \%$ of whom are children under the age of 5 , especially in developing countries. Some of the barriers include prevention of contamination, sanitation, and disinfection needed to effectively prevent the spread of waterborne diseases (Boutilier et al., 2014).

Indonesia is one of the developing countries covering many provinces, most still rely on water sources from river water alt- 2014).

hough the microbiological quality of river water does not meet health requirements. South Kalimantan is a province that is nicknamed the city of a thousand rivers because of the many rivers in this province, people in some cities use river water for everyday purposes especially bathing, washing, latrines. One of the largest rivers in South Kalimantan is the Martapura River located in Banjarmasin, still the residents of Banjarmasin defecate (BAB) in the Martapura River cause the level of contamination of Escherichia coli bacteria exceeds above the threshold (Rahmatullah, 2015).

The most common water-borne pathogens are bacteria (eg Escherichia coli, Salmonella typhi, Vibrio cholerae), viruses (eg adenovirus, enterovirus, hepatitis, rotavirus), and protozoa (eg Giardia). These pathogens cause child mortality and also contribute to malnutrition and impede child growth. (Boutilier et.al,

Diarrheal diseases in South Kalimantan are still included in one of the largest diseases of which the incidence is relatively high. This situation is supported by environmental factors, especially the poor condition of basic sanitation, such as the use of water for daily purposes that do not meet the requirements. 
The limited supply of clean water in some districts in south Kalimantan causes some people still use river water to meet daily needs such as bathing, washing, latrines and washing kitchen utensils including cutlery. Washing the cutlery using river water can cause disease transmission. Although people already use dish soap but possibly because the river water used is still contaminated with microorganisms.

As a result of the temporary observation, the people who live in the watershed, especially the Martapura River use the river water to wash dishes. How to wash dishes done by accommodating the river water in the basin. Plates that have been cleaned with soap and sponge are then rinsed with river water in the first basin and rinsed again using the second basin water. The dish soap commonly used by the Martapura River community is a solid form.

Necessary natural ingredients that are cheap and easy to obtain in the environment where living, natural materials that grow a lot around South Kalimantan and have the ability to reduce the microorganisms that contaminate the tools - the cutlery washed with river water.

Lime is one of the most widely known herbal plants for cough medicine, eliminating the fishy smell of the equipment. Several studies have shown that lime squeeze can be used as an antibacterial agent. Based on research Lauma et al (2015) squeeze of lime squeeze has an antibacterial effect in inhibiting the growth of Staphylococcus aureus bacteria. Aghnia research (2014) squeeze of lime squeeze has antimicrobial activity against Escherichia coli bacteria. Rahardjo (2012) revealed that lime squeeze as a decontaminant agent effectively decreases the amount of Salmonella and Escherichisa coli bacteria thoroughly on the chest of broiler chickens.

Antibacterial dishwashing soap is effective in reducing pathogenic bacteria (Kusumaningrum, et al., 2002). Antibacterial soap products are proven to significantly reduce bacteria by $98 \%$ (Holah JT, Hall KE., 2006). The greatest antibacterial activity with a $28 \pm 1.80 \mathrm{~mm}$ inhibitory zone resulted in a study of soap inhibition with the addition of essential oil of lime by $4 \%$ to Staphylococcus aureus bacteria (Apriyani D, TN Saifullah S., and Indrayudha I, 2013). Another study also produced a similar thing that is a radical zone against Staphylococcus aureus bacteria that is $(29.00 \pm 0.82) \mathrm{mm}$ using soap with the essential oil content of lemon (Rozi M, T.N. Saifullah S., and Indrayudha P, 2013).

Based on the above description has not known the effectiveness of soap with lime squeeze content in reducing the number of bacteria, if the is used in washing using river water in the washing model commonly used by the Martapura River area community. It is necessary to research the use of lemon soap that is made in the solid form to reduce the number of bacteria in the cutlery washed by using river water. This study aims to determine the effectiveness of contact time, and concentration of lemon soap in decreasing the number of bacteria in the utensil washed with water Martapura river.

\section{MATERIALS AND METHODS}

This research uses a pure experimental method with pretest and posttest with control research design. The research material used is Lime squeeze. The research material obtained from Banjarbaru market. The sample of the study is the dinnerware covering dinner plates of the same size. The independent variables are the lemon soap with the concentration of $40 \%, 50 \%, 60 \%$ and variable of contact time 30 second, 60 second and 90 seconds. The variable is bound to the number of bacteria on the dinnerware of a dinner plate.

The preparation of lemon squeeze soap has done with $40 \%, 50 \%$ and $60 \%$ concentration using Texopon $10 \mathrm{gr} / 100 \mathrm{ml}$ distilled water, XLS $5 \mathrm{gr} / 100 \mathrm{ml}$ distilled water, $\mathrm{NaCl} 10$ $\mathrm{gr} / 100 \mathrm{ml}$ distilled water, and lime squeeze as per concentration in a stir until homogeneous (Syafruddin, Kurniasih E., 2013). The MPN (Most Probable Number) coliform examination of martapura river water has used 555 varieties. The medium used Lactose broth (Merck) double strength and single strength, Brilliant Green Lactose Broth (Merck)

Examination Numbers bacteria have been using dinner plates of the same size. Group one washed with tap water and lemon soap concentration of $40 \%, 50 \%, 60 \%$ with a variation of contact time 30 seconds, 60 seconds and 90 seconds. The second group was washed using river water and lemon soap concentrations of $40 \%, 50 \%, 60 \%$ with contact time variation of 30 seconds, 60 seconds and 90 seconds. 
The third group washed with tap water and plain soap with variations of contact time 30 seconds, 60 seconds and 90 seconds. The fourth group has washed with river water and soap without lime with variations of contact time of 30 seconds, 60 seconds and 90 seconds. Work on the four groups performed repetition five times.

\section{RESULTS AND DISCUSSION}

The results of MPN coliform examination of river water showed results> 2400 CFU / $\mathrm{ml}$ sample. Treat dishwashing with plain soap and lemon squeeze soap $40 \%, 50 \%, 60 \%$ concentration. Contact time 30 seconds, 60 seconds and 90 seconds. Water used for rinsing in washing using tap water and Martapura River water. The resulting data can be seen in the table as follows

Table 1. Number of bacteria Treatment Lime Soap Concentrate $40 \%$ with Tap Water

\begin{tabular}{cccc}
\hline & \multicolumn{3}{c}{ Number of bacteria (/ml } \\
sampel) on the Contact Time \\
Repetition & 30 & 60 & 90 \\
& seconds & seconds & seconds \\
\hline 1 & 120 & 250 & 100 \\
2 & 420 & 0 & 150 \\
3 & 30 & 30 & 160 \\
4 & 140 & 2080 & 470 \\
5 & 100 & 110 & 370 \\
\hline
\end{tabular}

Table 2. Number of bacteria Treatment Lime Soap Concentrate $50 \%$ with Tap Water

\begin{tabular}{|c|c|c|c|}
\hline \multirow{2}{*}{ Repetition } & \multicolumn{3}{|c|}{$\begin{array}{c}\text { Number of bacteria }(/ \mathrm{ml} \\
\text { sampel) on the Contact Time }\end{array}$} \\
\hline & $\begin{array}{c}30 \\
\text { seconds }\end{array}$ & $\begin{array}{c}60 \\
\text { seconds }\end{array}$ & $\begin{array}{c}30 \\
\text { seconds }\end{array}$ \\
\hline 1 & 310 & 60 & 1350 \\
\hline 2 & 30 & 130 & 960 \\
\hline 3 & 90 & 50 & 320 \\
\hline 4 & 160 & 40 & 80 \\
\hline 5 & 590 & 510 & 1180 \\
\hline
\end{tabular}

Table 3. Number of bacteria Treatment Lime Soap Concentrate $60 \%$ with Tap Water

\begin{tabular}{cccc}
\hline & \multicolumn{3}{c}{ Number of bacteria (/ml } \\
Repetition & sampel) on the Contact Time \\
& 30 & 60 & 30 \\
seconds & seconds & seconds \\
\hline 1 & 21240 & 36453 & 5465 \\
2 & 30 & 310 & 1360 \\
3 & 60 & 10360 & 950 \\
4 & 50 & 1190 & 280 \\
5 & 0 & 1895 & 250 \\
\hline
\end{tabular}

Table 4. Number of bacteria Treatment Lime Soap Concentrate $40 \%$ with Water River

\begin{tabular}{cccc}
\hline & \multicolumn{3}{c}{ Number of bacteria (/ml } \\
Repetition & $\begin{array}{c}\text { sampel) on the Contact Time } \\
30\end{array}$ & 60 & 90 \\
& seconds & seconds & seconds \\
\hline 1 & 760000 & 1110 & 730 \\
2 & 512000 & 450 & 760 \\
3 & 680000 & 1520 & 2720 \\
4 & 536000 & 970 & 450 \\
5 & 602000 & 250 & 980 \\
\hline
\end{tabular}

Table 5. Number of bacteria Treatment Lime Soap Concentrate $50 \%$ with Water River

\begin{tabular}{cccc}
\hline & \multicolumn{3}{c}{ Number of bacteria (/ml } \\
Repetition & sampel) on the Contact Time \\
& 30 & 60 & 30 \\
& seconds & seconds & seconds \\
\hline 1 & 280000 & 8300 & 10300 \\
2 & 1340 & 144000 & 3590 \\
3 & 3480 & 4500 & 3780 \\
4 & 104000 & 650 & 260 \\
5 & 66000 & 3300 & 1450 \\
\hline
\end{tabular}

Table 6. Number of bacteria Treatment Lime Soap Concentrate $60 \%$ with Water River

\begin{tabular}{cccc}
\hline & \multicolumn{3}{c}{ Number of bacteria (/ml } \\
Repetition & sampel) on the Contact Time \\
& 30 & 60 & 30 \\
seconds & seconds & seconds \\
\hline 1 & 1310 & 340 & 430 \\
2 & 330 & 500 & 15200 \\
3 & 380 & 1160 & 9510 \\
4 & 420 & 670 & 250 \\
5 & 870 & 1210 & 330 \\
\hline
\end{tabular}

Table 7. Number of bacteria Treatment Soap with Tap Water

\begin{tabular}{cccc}
\hline Repetition & \multicolumn{3}{c}{$\begin{array}{c}\text { Number of bacteria (/ml } \\
\text { sampel) }\end{array}$} \\
$\begin{array}{cccc}30 \\
\text { seconds }\end{array}$ & $\begin{array}{c}60 \\
\text { detik }\end{array}$ & $\begin{array}{c}30 \\
\text { seconds }\end{array}$ \\
\hline 1 & 10 & 1204000 & 6800 \\
2 & 370 & 6280 & 8400 \\
3 & 60 & 1090 & 864000 \\
4 & 330 & 3405 & 21800 \\
5 & 230 & 970 & 1710 \\
\hline
\end{tabular}


Table 8. Number of bacteria Treatment Soap with Water River

\begin{tabular}{cccc}
\hline & \multicolumn{3}{c}{ Number of bacteria (/ml } \\
Repetition & $\begin{array}{c}\text { sampel) } \\
30\end{array}$ & 60 & 30 \\
& seconds & seconds & seconds \\
\hline 1 & 488000 & 48000 & 22000 \\
2 & 476000 & 26550 & 344000 \\
3 & 712000 & 18400 & 24300 \\
4 & 664000 & 82000 & 2000 \\
5 & 731000 & 12500 & 3900 \\
\hline
\end{tabular}

Based on the data in the table above is done data normality test using Shapiro-Wilk test first, to determine whether the data used normal distribution or not. The result of data normality test analysis by using Shapiro-Wilk test, it can be stated that the data is not normally distributed although data transformation has been done. The next test is a nonparametric Kruskal-Wallis test.

Number of bacteria after washing with lemon soap and soap without lime with contact time in the test using Kruskal Wallis showed a significance value of 0.796 (> 0.05), which means there is no significant difference in treatment with contact time variation of $30 \mathrm{sec}-$ onds, 60 seconds and 90 seconds.

The number of bacteria of soap treatment of various concentration and soap without lime with Kruskal Wallis test showed a significance value of $0.000(<0,05)$, meaning that there is significant difference to the number of germ of soap treatment of various concentration and soap without lime.

To know the difference of each concentration of lemon soap and soap without lime, then Mann Whitney test. Mann Whitney test results showed no difference in each treatment across all concentrations of lemon soap, and there was a difference in $40 \%$ lemon soap treatment with soap without lime, 50\% concentrated lemon soap with soap without lime, $60 \%$ lemon soap plain soap.

The Water Treatment Gaps of tap water and river water tested using Mann Whitney shows a significance value of $0.000(<0.05)$, meaning that there is a significant difference to the tap water and river water.

The results showed that there was a difference in the number of bacteria washing with lemon soap with lemonless soap (tables 7 $\& 8)$. The ability of an antibacterial agent to inhibit the life of microorganisms depends on the concentration of antibacterial agents. This means that the amount of antibacterial ingredients in a germ environment will determine the life of the exposed bacteria. In this study the concentration value used $40 \%, 50 \%$ and $60 \%$.

Bacterial growth can be inhibited by the essential oils and flavonoids present in the lime. The essential oil works by denaturing the bacterial cell protein and destroying the cell's cytoplasmic membrane. The denatured protein loses physiological activity and instability in the cell wall increases cell permeability, the transport function becomes active, the control of the protein structure of the bacterial cell is disrupted resulting in the escape of macro molecules and ions from the cell. The cells will lose their shape so that the lysis and damage. While flavonoids have bacteriostatic or bactericidal properties depending on their concentration, inhibiting bacterial growth by interacting directly with DNA, causing bacterial DNA to be damaged so that the bacteria die (Sumono \& Wulan, 2008). This is because DNA or RNA plays an important role in the normal cell life process. This means any interference that occurs in the formation or on the function of the substance can cause total damage to the cell (Rahayu \& Winiati, 2000).

Several other studies on lemon squeeze show obstacles to certain bacteria. The results of the experiment showed that resistance to Staphylococcus aureus bacteria at concentrations of $25 \%, 50 \%, 75 \%$ and $100 \%$ with inhibitory zones inhibit the growth of Staphylococcus aureus bacteria in vitro by Razak (2013) which is formed at $5.167 \mathrm{~mm}$, $6.167 \mathrm{~mm}, 7.7 \mathrm{~mm}$ and $10.5 \mathrm{~mm}$.

The results of the experiment showed that the increase of inhibited drag zone at concentrations of $12.5 \%, 25 \%, 50 \%$, and $75 \%$ with the measurement of the diameter of the zones the average inhibition is $8.5 \mathrm{~mm}, 16 \mathrm{~mm}$, $19.5 \mathrm{~mm}$, and $23.5 \mathrm{~mm}$.

This study shows that there are differences in the number of bacteria on treats using PDAM water and river water. Water taps are water that has been through the processing, so the possibility of bacteria in the water does not exist or minimal. Martapura river water used shows the results of MPN coliform $>2400 \mathrm{CFU} / \mathrm{ml}$ to allow the results of research using this river water to produce more bacteria. 


\section{CONCLUSION}

There were no significant differences in treatment with contact time variation of $30 \mathrm{sec}-$ onds, 60 seconds and 90 seconds with a significance value of 0.796 ( $>0.05)$. There were significant differences in the treatment of lemon soap with concentration variations of $40 \%$, $50 \%, 60 \%$ and soap without lime with a significance value of $0.000(<0.05)$. There is no effective concentration of lemon soap and effective contact time to decrease the number of bacteria.

\section{REFERENCES}

Aghnia H.S. (2014). Aktivitas antimikroba Air Perasan Jeruk Nipis (Citrus aurantifolia) terhadap Escherichia coli Secara In Vitro.

Boutilier M.S.H, Lee J, Chambers V, Venkatesh V, Karnik R. (2014). Water Filtration Using Plant. PLOS ONE, 9(2), e89934.

Brillian B. (2014). Salmonella infections Human - Medicine. Universitas Syiah Kuala.

Holah J.T, Hall K.E. (2006). The effect of an antibacterial washing-up liquid in reducing dishwater aerobic plate counts: Lett Appl Microbiol, 42(5), 532-7.

Kusumaningrum H.D, Van Putten MM, Rombouts. F., \& RR, Beumer. (2002). Effects of antibacterial dishwashing liquid on foodborne pathogens and competitive microorganisms in kitchen sponges. J Food Prot, 65(1), 61-5.

Lauma et al. (2015). Uji Efektivitas Perasan Air Jeruk Nipis (Citrus aurantifolia S) Terhadap Pertumbuhan Bakteri Staphylococcus aureus Secara In Vitro. PHARMACON Jurnal IImiah Farmasi-UNSRAT, 4 (4).

Rahardjo, A. H. D. (2012). Efektivitas Jeruk Nipis dalam Menurunkan Bakteri Salmonella Dan Escherichia coli Pada dada Karkas Ayam broiler. Indonesian Journal Of Applied Science (IJAS), 2(3).

Rahayu, P., \& Winiati. (2000). Aktivitas Antimikroba Bumbu Masakan Tradisional. Journal of Medicinal Plant Research., 4.

Rahmatullah. (2015). Sungai Martapura Tercemar. Banjarmasin Post.

Razak A, Djamal A, Revilla G. (2013). Uji Daya Hambat Air Perasan Jeruk Nipis (Citrus aurantifolia) Terhadap Pertumbuhan Bakteri Staphylococcus aureus Secara in vitro. Jurnal Kesehatan Andalas.

Rozi M, T. N. Saifullah S. Indrayudha $P$. (2013). Formulasi sediaan sabun mandi transparan minyak Atsiri jeruk nipis (citrus aurantifolia) dengan cocamid dea Sebagai surfaktan. Universitas Muhammadiyah Surakarta.

Sumono, A., \& Wulan, A. (2008). Dental Jurnal. The use of bay leaf (Eugenia polyantha Wight) in dentisty. Dental Jurnal, 41.

Syafruddin, \& Kurniasih, E. (2013). Aplikasi minyak nilam sebagai bahan aditif sabun transparan antiseptik. Jurnal MANTEKH, 5(1). 